\title{
СТАНОВЛЕННЯ ОПОЗИЦЙНОГО ПАРЛАМЕНТСЬКОГО БЛОКУ У ВЕРХОВНІЙ РАДІ УКРАЇНСЬКОЇ РСР (1990 р).
}

\author{
Ігор ПІДКОВА \\ Львівський національний університет імені Івана Франка \\ кафедра новітньої історії України імені Михайла Грушевського \\ вул, Університетська, 1, 79000, Львів, Україна \\ e-mail: ihorpidkowa@gmail.com
}

Висвітлено процес організаційного формування опозиційного депутатського об'єднання у Верховній Раді Української РСР ХІІ скликання. Відзначається, що формувати парламентську опозицію довелось в умовах жорсткого політичного протистояння з комуністичною більшістю парламенту. У парламентський блок «Народна Рада» увійшли представники різних ідейнополітичних течій, що перебували на спільних політичних платформах - антикомунізму, антитоталітаризму, антиунітаризму і демократизму. У своєму програмному маніфесті Народна Рада задекларувала реформу політичної системи в республіці на основі трьох засадничих принципів - суверенітет, багатопартійність і різноманітність форм власности. Опозиційне об'єднання сформувалося як мультифракційний загальнополітичний парламентський блок у складі кількох фракцій, кожна з яких мала власне бачення суспільно-політичної ситуації в республіці, цілей і методів дій опозиційних сил. У протиборстві та взаємодії двох парламентських сил - Народної Ради і консервативно-комуністичної більшісти поступово витворювалися контури майбутньої державности України. Опозиційне коаліційне об'єднання депутатів - Народна Рада, використовуючи методи парламентської та позапарламентської діяльности, змінюючи республіканську законодавчу базу, сприяло демократичним процесам у республіці й повело боротьбу за реальний суверенітет України.

Ключові слова: Верховна Рада України, Демократичний блок, Союз демократичних сил, Народна Рада, компартійна більшість, депутатська група, “За радянську суверенну Україну”, парламентаризм.

Трансформаційні процеси другої половини 1980-х років у СРСР спричинили кардинальні зміни в політичній структурі суспільства і започаткували докорінну реорганізацію принципів діяльности найвищих органів влади і на загальносоюзному, і на республіканському рівнях. Важливим етапом у реформуванні радянського політичного режиму на регіональному рівні стали вибори до Верховних Рад союзних республік, зокрема й Української РСР.

У березні 1990 р., внаслідок лібералізації республіканського виборчого законодавства та зростання масовости й політизованости демократичного руху, відбулися відносно вільні й змагальні вибори до вищого законодавчого органу республіки - Верховної Ради Української РСР. За результатами виборчих перегонів уперше за десятиріччя існування радянської системи опозиційні комуністичній системі діячі увійшли до складу парламенту та з трибуни найвищого законодавчого органу республіки задекларували свої політичні переконання й цілі. 
ISSN 2078-6077. Наукові зошити історичного факультету Львівського університету. 2018-2019. Випуск 19-20. Proceedings of History Faculty of Lviv University. 2018-2019. Issue 19-20.

До відкриття парламентської сесії новообраного найвищого законодавчого органу республіки ретельного готувалися і компартійна влада, і опозиція. Лейтмотивом усіх кроків політичних опонентів стала боротьба за опанування радянських структур, саме в яких поступово почали зосереджуватись реальні важелі влади в республіці.

Використавши перемогу на місцевих виборах, функціонери Комуністичної партії України (КПУ) очолили Ради різних рівнів - від обласних до районних. Так, головами обласних Рад стали перші секретарі обкомів партії у Дніпропетровську, Житомирі, Миколаєві, Одесі, Сумах, Тернополі, Херсоні, Ужгороді, Черкасах. Враховуючи те, що у низці регіонів опозиція прийшла до влади й тепер могла використовувати у своїх цілях владні інститути, партапарат вдався до контрзаходів. Для мінімалізації інформаційного впливу демократичних сил на інші регіони республіки й для утримання під своїм контролем силового блоку виконавчої влади, старий склад Президії Верховної Ради на останньому своєму засіданні видав указ про позбавлення місцевих Рад права керівництва ЗМI та управліннями внутрішніх справ. Крім адміністративних заходів, партапарат, за твердженням голови Львівської обласної Ради В. Чорновола, розпочав економічну блокаду областей, де “народ спробува усунути Компартію від влади". Одночасно “апаратні ігри” розпочалися і довкола відкриття першої сесії Верховної Ради 12 скликання.

Прагнучи відразу взяти під свій контроль роботу новообраного парламенту, партапарат доручив готувати сесію парламенту секретареві Президії Верховної Ради попереднього скликання Миколі Хоменку². За його ініціятивою вже 10 квітня 1990 р. запрацювала підготовча група у складі 91 депутата (норма представництва від областей, міст Києва і Севастополя була встановлена 3 розрахунку 1:5), однак, незабаром їі кількісний склад, незважаючи на протести депутатів від опозиційного виборчого блоку (Демократичного блоку України), був скорочений до 27 осіб. Статус групи не був юридично визначений, то ж навколо іiі функцій і складу велись тривалі дискусії.

Представників до складу робочої комісії визначили на засіданнях територіяльних депутатських груп, то й не дивно, що більшість складали керівники партійно-державного апарату. Так, від житомирської делегації увійшли 1-й секретар Житомирського обкому КПУ В. Федоров та 1-й секретар Коростишівського райкому КПУ М. Борейко, черкаської - 1-й секретар Чорнобаївського райкому КПУ І. Пасічник, одеської - 2-й секретар Одеського обкому КПУ М. Снігірьов та голова облради, член центрального комітету КПУ

1 “Виступ народного депутата УРСР В. Чорновола”, Бюлетень Верховної Ради УРСР, №. 23, (1990): 56.

${ }^{2}$ Напередодні відкриття роботи парламенту нового скликання було проведено реорганізацію апарату Президії Верховної Ради Української РСР, внаслідок чого було створено п’ять нових підрозділів, з яких чотири очолили керівники відділів ЦК КПУ і один перший секретар обкому КПУ. 
А. Печеров, полтавської - голова облвиконкому I. Гопей та ін. Від групи опозиційних депутатів у засіданнях узгоджувальної комісії брали участь депутати Я. Дмитришин, В. Валеня, В. Карпенко, С. Хмара, І. Макар, О. Чародєєв, В. Філенко, В. Гусєв, О. Смець та В. Веретенніков. Опозиційні депутати становили явну меншість складу оргкомітету і, як з'ясувалось незабаром, реально впливати на хід роботи групи не мали змоги.

Проєкт порядку денного першої сесії, який запропонував М. Хоменко, приймався “з голосу” у режимі максимального поспіху. Пропозиція секретаря парткому шахти О. Чародєєва продовжувати роботу до врегулювання всіх спірних питань була проігнорована комуністичною більшістю робочої групи. Такий підхід до вирішення питань організаційного забезпечення роботи майбутнього парламенту міг свідчити лише про те, що більшість депутатів не до кінця усвідомлювали особливість діяльности парламенту на постійній основі. На сприйняття парламентської сесії як чогось вторинного в політичному житті республіки вказував і спосіб визначення строків ії проведення, яка на думку більшости оргкомітету мала тривати від 5 травня до 6 червня. Дата закінчення роботи сесії була встановлена керівництвом КПУ із урахуванням термінів роботи XXVIII з'їзду КПУ (за твердженням опозиційних депутатів), відкриття якого припадало на 19 червня. Така позиція більшости комісії викликала рішучі протести з боку опозиції. Обговорюючи проєкт порядку денного роботи сесії, члени зборів представників від демократичних сил вносили пропозиції розглянути закони про владу (Ярослав Дмитришин), про обрання президента (Віталій Карпенко), статус Верховної Ради (Степан Хмара), про місцеве самоврядування (Віктор Гусєв), вимагали створити постійні комісії 3 питань Чорнобильської катастрофи, з питань гласности та прав людини, 3 питань економічної реформи, 3 питань релігії тощоз Щоб непорушувати закон про мови депутатам, які не володіють державною мовою, пропонувалося утримуватися від виступів. Однак, більшість пропозицій демблоківців не розглядалася. Усі функції погоджувальної групи зводились до обміну думками іiі учасників, а рішення приймались за заздалегідь визначеним сценарієм. Складалося враження, що парламентські процедури, які передбачають враховувати права та інтересів меншости - невідомі партапаратчикам, які, незважаючи ні на що, втілювали визначені у вищих партійних кабінетах завдання. Все це дало підстави депутату-рухівцю Павлові Мовчану у перші дні роботи парламенту констатувати: “порядок денний складений не нами, поза нами, i накинений нам"4

Апогеєм нехтування прав меншости у роботі з підготови сесії стало формування робочої групи сесії Верховної Ради, до складу якої не увійшов жоден

\footnotetext{
${ }^{3}$ Олександр Сугоняко, Верховна Рада України ХІІ скликання. 1990-1994 роки. (Київ: “Кий”, 1998), 407-408.

4 “Виступ народного депутата УРСР П. Мовчана", Бюлетень Верховної Ради УРСР, o. 3, (1990): 15-16.
} 
ISSN 2078-6077. Наукові зошити історичного факультету Львівського університету. 2018-2019. Випуск 19-20. Proceedings of History Faculty of Lviv University. 2018-2019. Issue 19-20.

представник демократичних сил. То ж ще до початку роботи новообраного парламенту народний депутат Олександр Сугоняко, підводячи підсумки 3 підготови сесії парламенту вказував на недієвість демократичних механізмів у протистоянні з партапаратом й зазначав, що Верховна Рада може йти “дорогою демократії тільки за відчутної політичної підтримки виборців. В іншому випадку цей “слон” - апарат і далі хазяйнуватиме у нашій “посудній лавці"5.

Верховна Рада Української РСР ХІІ відкрила своє перше засідання 15 травня 1990 р., коли в сесійному залі зареєструвалося 424 парламентарії із 449 народних депутатів. У виступі голови Центральної виборчої комісієї зазначалося, що у виборах 4 березня 1990 р. взяло участь понад 31 мільйон осіб, тобто, майже $85 \%$ виборців ${ }^{6}$.

Відразу після оголошення ЦВК виборів дійсними, у демократичному середовищі розпочалися активні консультації з формування опозиційної парламентської коаліції. Питання назви майбутнього опозиційного парламентського об'єднання тривалий час дискутувалося, непостійним залишався і його особовий склад. У ході консультацій для його означення найчастіше вживалася назва “Демократичний блок”, інколи - Союз демократичних сил, або Блок демократичних сил. Діяльність парламентського Демократичного блоку, до створення Народної Ради, координував голова Львівської крайової організації НРУ Орест Влох ${ }^{7}$.

Політична боротьба, яка точилася під час всієї передвиборчої кампанії, 3 початком пленарних засідань парламенту не тільки не затихла, розгорнулася 3 новою силою. Особливо гострі дебати спалахнули довкола обрання робочої президії Верховної Ради і порядку денного сесії. Уже на перших хвилинах роботи сесії депутати від Демблоку звинуватили партапарат у спробі захопити керівництво парламентом шляхом маніпуляцій. “...Результати, які видаються як рекомендації зборів представників, є ніщо інше, як спроба апарату, прикриваючись цими зборами, нав' язати Верховній Раді свій сценарій роботи”, констатував депутат С.Головатий ${ }^{8}$. Всі кандидатури, які запропонував Демблок до складу президії (Іван Валеня, Олександр Чародєєв, Олександр Смець, Сергій Головатий, Іван Салій), були провалені, а їі членами обрані лише представники більшости. Власне під час голосування включити до складу робочої президії кандидата від Демократичного блоку Івана Валені на парламентському табло вперше висвітлилось число “239” - саме стільки депутатів увійшли згодом до комуністичної більшости у парламенті. До складу робочої групи парламенту

\footnotetext{
${ }^{5}$ Олександр Сугоняко. Верховна Рада Украӥни ХІІ скликання. 1990-1994 роки, 409.

6 “Виступ голови ЦВК по виборах народних депутатів УРСР 15 травня 1991 р“, Бюлетень Верховної Ради УРСР, No. 1, (1990): 3.

${ }^{7}$ Олександр Барабаш. Верховна Рада України ХІІ скликання. 1990-1994 роки. (Київ: “Кий”, 1998), 529.

8 “Виступ народного депутата УРСР С. Головатого", Бюлетень Верховної Ради УРСР, o. 1, (1990): 7.
} 
увійшли лише представники партапарату - М. Артеменко, М. Гавриленко, С. Макаренко, С. Остроущенко та I. Плющ.

Рядові парламентські процедури з обрання складу робочої президії, формування секретаріяту та лічильної комісії перетворилися на гострі політичні баталії, під час яких стало очевидно, що Демблок має мінімальні шанси вирішувати організаційні питання, оскільки партапарат запустив “машину для голосування" і будь-які пропозиції некомуністичної меншости блокуватимуться.

Першою сконсолідованою акцією Демблоку у Верховній Раді став виступ проти намагання більшости запровадити трансляцію роботи сесії у редагованому форматі. У парламентській залі вперше прозвучала узгоджена заява опозиції про неприпустимість "позбавляти народ можливості в повному обсязі спостерігати за роботою своїх обранців, бути співучасниками процесу законотворчості”, що, у підсумку, спричинилось до трансляції пленарних засідань у повному обсязі.

Гостра парламентська полеміка розгорнулась щодо формування порядку денного роботи сесії. До порядку денного було включено 23 пункти: обрання Голови Верховної Ради та його заступників; формування республіканського уряду, Верховного Суду, Комітету Конституційного нагляду; прийняття законів про регламент і постійні парламентські комісії, про статус народного депутата; затвердження Декларації про державний суверенітет; звернення про укладення нового Союзного договору та ін. Демблок пропонував винести на розгляд парламенту питання, які, в основному, мали політичний підтекст. Депутатидемблоківці Левко Лук'яненко, Ірина Калинець, Петро Осадчук наполягали на звіті про політичне, соціяльно-економічне і екологічне становище в Україні. Після двох днів гарячих дискусій вимогу щодо звіту Ради Міністрів про ситуацію у республіці підтримали й депутати більшости. Зокрема, голова Ради з вивчення продуктивних сил Української РСР АН УРСР Сергій Дорогунцов зазначав: “Звіт уряду, справедлива вимога... Де ми знаходимося, і чи ми зупинилися перед прірвою, чи ми полетимо туди вниз",

Активність і зацікавленість обговорення порядку денного народними обранцями, попри властиву багатьом з них надмірну емоційність, вселяла надію, що робочі засідання Верховної Ради щораз більше входитимуть у конструктивне русло. Багато хто 3 депутатів реально оцінював ситуацію в парламенті й закликав, що представників різних течій визнати право політичних опонентів на відстоювання власної позиції. Проте, на практиці досягнути конструктивного діялогу не вдавалось. Причому до проявів нетерпимости й певної провокативности у заявах і діях (нерідко цілком свідомих) вдавалась і більшість, i опозиція. Складалось враження, що прагнення щоболючіше “вколоти" політичного опонента інколи брало гору над потребою пошуку компромісу задля

9 “Виступ народного депутата УРСР С. Дорогунцова", Бюлетень Верховної Ради УРСР, No. 4, (1990): 12. 
ISSN 2078-6077. Наукові зошити історичного факультету Львівського університету. 2018-2019. Випуск 19-20. Proceedings of History Faculty of Lviv University. 2018-2019. Issue 19-20.

налагодження продуктивної роботи. Так, неприхований антикомунізм деяких представників Демблоку, викликав гостру реакцію депутатів з більшости й на тривалий час заблокував роботу парламенту. Вимога депутата Миколи Поровського прибрати з сесійної зали скульптуру В. Леніна, спричинила шквал обурення депутатів-комуністів ${ }^{10}$ Демарш свого колеги 3 опозиції засудив В. Яворівський, який зайняв гнучкішу для цього моменту позицію, заявивши: "Не завдання парламенту вносити або виносити скульптури... Люди, які прийшли у парламент повинні забути... про свою партійну приналежність, свої ідеологічні стереотипи. Ми, парламентарії, передусім творимо закони для свого народу"11.

Конфронтаційні ситуації в парламенті виникали під час розгляду найрізноманітніших питань. Так, зволікання з прийняттям рішення про озвучення площі перед Верховною Радою та отримання дозволу на проведення мітингів біля стін Верховної Ради (як вже зазначалося, Демблок дуже розраховував на публічну підтримку громадянами своїх парламентських ініціятив) викликало чергову парламентську “мінікризу”. Зрештою, це питання було врегульовано, але не останньою чергою через погрозу депутатів-демблоківців залишити сесійну залу.

За кілька днів пленарних засідань у кожної з протиборчих сторін виробилась своєрідна тактика: демблоківці з парламентської трибуни пропагували свої погляди; їхні суперники, маючи більшість, - використовували механізм голосування. Л. Лук'яненко, один із лідерів парламентської опозиції, описуючи початковий період роботи Верховної Ради, пізніше згадував: “Ми дуже багато виступали, галасували. А вони - голосували проти нас, і своїми рішеннями відкидали будь-яку нашу ініціятиву" ${ }^{2} .3$ цього приводу кулуарами парламенту навіть ходив жарт - “Демблок бере галасуванням, партапарат голосуванням"13.

Ключовим питанням у протиборстві опозиції й більшости стало обрання керівництва Ради. Перебіг цих виборів наочно підтвердив, що в українському політикумі на першому місці стоїть питання боротьби за владу, а не державний інтерес. Демократичний блок, незважаючи на некорисний для себе розклад сил у парламенті, активно включився в цю боротьбу.

Опозиційні депутати наполягали на першочерговому прийнятті змін статтей до 6 і 7 Конституції (тобто, визнати де-юре багатопартійність), прийнятті Декларації про державний суверенітет України ${ }^{14}$, а вже опісля розглянути організаційні питання. Логіка демблоківців полягала в тому, що новообране

\footnotetext{
${ }^{10}$ Микола Поровський. Тільки РУХом життя обіймеш... Повість-спогад”. (Рівне, 2009), 200.

11 "Виступ народного депутата УРСР В. Яворівського", Бюлетень Верховної Ради УРСР, No. 23, (1990): 14.

12 Левко Лук'яненко. “І не набрався скверни”. Украӥна, вересень 1990: 9.

${ }^{13}$ Віталій Карпенко “Займіть свої місця...”. Вітчизна, 1991, №. 4: 140.

14 “Виступ народного депутата УРСР В. Гриньова”, Бюлетень Верховної Ради УРСР, №. 23, (1990): 27.
} 
керівництво парламенту повинне стояти на позиціях економічного і політичного суверенітету України, про що від імени Демблоку заявив С. Головатий: “Ми пропонуємо прийняти Декларацію про державний суверенітет, оскільки це буде та вихідна, з якої почне свою законодавчу діяльність Верховна Рада України нового скликання" ${ }^{15}$. Ідея республіканського суверенітету знаходила схвалення й у частини депутатів, які позиціонували себе як “незалежні”. Зокрема, директор заводу з Донеччини В. Новіков заявив: "Нам потрібно представити, які наші можливості... тобто, наскільки ми будемо самостійні в політичному руслі..., наскільки ми зможемо приступити до вирішення всіх питань" ${ }^{\prime 16}$. Його підтримав ще один представник директорського корпусу з Дніпропетровщини Василь Євтухов, який стверджував, що розв'язання інших питань неможливо без вирішення питання про суверенітет.

Однак, пропозиція про розгляд питання про суверенітет, як і можна було очікувати, не дістала підтримки у більшости депутатів. Й було зрозуміло чому. Головним завданням на цьому етапі роботи сесії комуністична більшість вбачала в обранні Головою Верховної Ради першого секретаря Компартії Володимира Івашка, кандидатура якого вже була вже була узгоджена 3 генеральним секретарем ЦК КПРС Михайлом Горбачовим ${ }^{17}$.

Члени Демблоку взяли найактивнішу участь у процедурі обрання Голови Верховної Ради. Із 12 кандидатур, запропонованих на посаду спікера парламенту, десять або входили до Демблоку (Михайло Горинь, Іван Драч, Віталій Карпенко, Левко Лук'яненко, Дмитро Павличко, В'ячеслав Чорновіл, Володимир Яворівський, Ігор Юхновський), або тісно співпрацювали із ним (Володимир Гриньов та Іван Салій). І лише двоє претендентів на вищий державний пост у республіці репрезентували Компартію - Станіслав Гуренко і Володимир Івашко.

Процедуру висунення і обговорення кандидатур опозиційний парламентський блок розглядав як тактичний хід для критики політики Компартії, пропагування демократичних цінностей і завоювання політичних симпатій широких верств суспільства. Характеризуючи тактичні плани опозиції в той період, В. Чорновіл зазначав: "Головне завдання нашої меншости - пропагандистське: продемонструвати хто $є$ хто, показати справжнє обличчя партократії, яка прорвалася до влади і потім поставити народ перед питанням - а чи потрібен нам такий парламент"18.

Як кандидати на посаду спікера парламенту, члени демократичного корпусу Верховної Ради, вперше звернулися до багатомільйонної авдиторії й задекларували свої погляди у всеукраїнському масштабі. Завдяки трансляції

15 “Виступ народного депутата УРСР С. Головатого”, Бюлетень Верховної Ради УРСР, No. 3, (1990): 12 .

16 “Виступ народного депутата УРСР В. Новікова”, Бюлетень Верховної Ради УРСР, №. 3, (1990): 15.

17 Леонід Кравчук. Маємо те, щзо маємо. Спогади і роздуми (Київ: Століття, 2002), 51.

${ }^{18}$ В'ячеслав Чорновіл. “Тяжка ноша демократичних сил”, Молода Украӥна. 1990, No. 10: 1. 
ISSN 2078-6077. Наукові зошити історичного факультету Львівського університету. 2018-2019. Випуск 19-20. Proceedings of History Faculty of Lviv University. 2018-2019. Issue 19-20.

сесії громадяни України ознайомилася із державотворчими програмами колишніх дисидентів Л. Лук'яненка, М. Гориня, В. Чорновола, яких компартійна преса раніше називала не інакше як “буржуазними націоналістами”, почула пристрасні виступи I. Драча, В. Яворівського, Д. Павличка. Програмні виступи претендентів-демократів швидше нагадували політичні маніфести, ніж реальні програми дій. 3 одного боку, втілення їх у життя видавалося проблематичним із цим складом парламенту, з іншого - найактивніші лідери опозиції вже встигли заявити про неможливість будь-яких компромісів із “новим класом апаратників, що пройшли школу Брежнєва, Щербицького, академії застою і зараз перелицювалися в перебудовників" 19 .

Певним відкриттям для депутатського корпусу і всеукраїнської авдиторії став академік І. Юхновський. На відміну від попередніх кандидатів Л. Лук'яненка чи В. Чорновола виступ цього відомого науковця не містив політичних випадів у бік Компартії на зразок "на лаву підсудних, бодай і символічну, треба посади саму існуючу політичну систему" 20 . Більше того, І. Юхновський вважав, що "бюрократичний апарат, який зараз існує в республіці, готовий до того, щоб забезпечити республіці її суверенітет”. На його думку, головною вимогою ефективної роботи адміністративного апарату в нових умовах $€$ зміна “напряму руху республіки” і розуміння того, що “нова політика має творитися новою верхівкою"21. Програма I. Юхновського давала прагматичну оцінку ситуації в економічному i, меншою мірою, політичному житті республіки, накреслювала шляхи подолання кризи, тому й викликала схвальні відгуки у частини депутатського корпусу, зокрема, керівників великих підприємств. Та й сама постать I. Юхновського - комуніста, ветерана війни, члена Руху і вченогоінтелектуала могла, за певних обставин, відіграти консолідуючу роль у парламенті.

Прихильником “загальнодемократичних принципів” позиціонував себе ще один кандидат від опозиції, представник “Демплатформи в КПУ”, професор В. Гриньов із Харкова. Це був єдиний кандидат, який виступав російською мовою. Його позиція щодо політики “українізації”, викликала нерозуміння і критику навіть у земляків-харків' ян. Зокрема, народний депутат А. Сухоруков, за його словами “теж космополіт”, зазначав: “Що ж Ви, Володимире Борисовичу, сорок років прожили на Україні, і не змогли мови трошки вивчити. Це ж не зовсім, як кажуть, по-інтелектуальному, по-професорськи"22. Погляди В. Гриньова щодо майбутнього Союзної держави (“Я ближче до ідеї Сльцина: більше, ніж федерація,

19 “Виступ народного депутата УРСР В. Чорновола", Бюлетень Верховної Ради УРСР, №. 23, (1990): 53.

${ }^{20}$ Там само: 51.

21 “Виступ народного депутата УРСР І. Юхновського", Бюлетень Верховної Ради УРСР, №. 21, (1990): 58

22 “Виступ народного депутата УРСР А. Сухорукова", Бюлетень Верховної Ради УРСР, №. 25, (1990): 53. 
але не доходячи до конфедерації”), форми державного устрою України (“На мій погляд, більше всього підходить для цього механізм федерації”) ${ }^{23}$ і двомовности, сприймали неоднозначно у середовищі навіть центристськи налаштованих депутатів опозиції. Інтелектуальний рівень програм I. Юхновського і В. Гриньова високо оцінювали і представники партійної більшости. Зокрема, депутат Анатолій Толстоухов зазначав: "Нема слів, кандидати І. Юхновський і В. Гриньов виглядали достатньо переконливо, інколи навіть привабливіше, ніж В. Івашко”24.

У ході обговорення кандидатур стало очевидним, що у парламенті йде змагання не програм, а протиборство двох систем поглядів - комуністичної та демократичної - й жодні аргументи тут не діють. Суть того, що відбувалося, точно охарактеризував демблоківець Дмитро Захарук: “Давайте не лукавити. Говорімо просто, хочемо Івашка, бо так нам велить партійна дисципліна"25. Депутат О. Сугоняко так підсумовував події на сесії: "3 демонополізацією політичної влади апарат вже змирився на практиці. 3 демонополізацією влади він поки що погоджується лише на словах"26.

Серед кандидатур на посаду Голови парламенту був і відомий своїми ліберальними поглядами секретар Подільського райкому I. Салій. Основні тези його програми (багатопартійність, формування коаліційного уряду й суверенітет на основі Союзного договору) звучали в унісон з головними програмними тезами демократів, що сприймали як політичну єресь ортодоксальні однопартійці. У цій ситуації головний комуніст київського Подолу не міг розраховувати на вагому підтримку у залі й свою участь у виборах аргументував так: “Я не знімаю свою кандидатуру тому, щоб комуністи в умовах фактичної однопартійності перестали бути одностайними"27.

Останньою спробою заблокувати обрання В. Івашка стала заява Демблоку про недопустимість суміщення посад Голови парламенту із виконанням інших обов' язків на професійній чи громадській основі (тут йшлося про секретарство В. Івашка у ЦК КПУ $)^{28}$, однак, більшість депутатського корпусу не прислухалася до аргументів опозиції. На знак протесту Демблок оголосив про свою неучасть у виборах, спрямованих “на встановлення диктату верхівки Компартії України у вищих структурах Верховної Ради”, й розцінив це голосування як “заперечення

23 “Виступ народного депутата УРСР В. Гриньова”, Бюлетень Верховної Ради УРСР, №. 23, (1990): 36.

24 “Виступ народного депутата УРСР А. Толстоухова", Бюлетень Верховної Ради УРСР, №. 28, (1990): 29

25 “Виступ народного депутата УРСР Д. Захарука", Бюлетень Верховної Ради УРСР, №. 26, (1990): 10.

${ }^{26}$ Там само.

27 “Виступ народного депутата УРСР І. Салія”, Бюлетень Верховної Ради УРСР, No. 28, (1990): 18-19.

28 “Виступ народного депутата УРСР О. Воробйова", Бюлетень Верховної Ради УРСР, №. 25, (1990): 5 . 
ISSN 2078-6077. Наукові зошити історичного факультету Львівського університету. 2018-2019. Випуск 19-20. Proceedings of History Faculty of Lviv University. 2018-2019. Issue 19-20.

принципу розподілу влади, концепції правової держави і суверенітету України, а також порушенням основ справжнього народовладдя" 29.

Результати виборів Голови парламенту були передбачувані - за В. Івашка проголосувало 278 депутатів, В. Гриньов набрав 28 голосів, І. Салій -4 , а I. Юхновського підтримали 24 депутати. Обрання В. Івашка Демблок розцінив як фактичне захоплення влади Компартією у Верховній Раді. Один із лідерів демократичної опозиції у республіці, народний депутат СРСР Володимир Черняк вказував на помилковість тактики бойкотування виборів голови парламенту. "Вважаю ми часто збиваємося на істерику. А це політика. А політика вимагає певної гнучкости”, - зазначав він.

Організаційне оформлення парламентської опозиції прискорили події, пов'язані з обранням заступників Голови парламенту. Опозиційні депутати, деякий час, виходячи із заяв новообраного Голови парламенту про "принцип гармонії інтересів", розраховували на пропорційне представництво демократичних сил у парламентських і урядових структурах ${ }^{30}$.

Відтак 5 червня 1990 р. відбулося засідання Демблоку, на якому ухвалено сформувати парламентську коаліцію демократичних сил у Верховній Раді для “створення нового порядку в республіці на основі трьох принципів - суверенітету, багатопартійности і різних форм власности”. Головою опозиційного об'єднання депутатів, яке отримало назву "Народна Рада", був обраний академік I. Юхновський. Народорадівці запропонували кандидатуру І. Юхновського на посаду першого заступника Верховної Ради як “постать, котра могла б внести рівновагу в спільну парламентську діяльність”. Одночасно, як компромісний варіянт, Демблок пропонував встановити інститут двох перших заступників, із тим, щоб один із них репрезентував інтереси парламентської меншости ${ }^{31}$.

Після відмови комуністичної більшости підтримати кандидатуру I. Юхновського, 6 червня 1990 р. депутат Яків Зайко зачитав заяву, де вперше офіційно йшлося про перехід демократичної меншости до "конструктивної опозиції, яка буде організаційно оформлена у вигляді Народної Ради”. У виступі наголошувалося: "Вважаємо неприпустимою для депутатів від Демблоку будьяку участь у керівництві Верховної Ради вище рівня постійних комісій, бо це б створювало ілюзії консолідації з силами застою". Головними своїм завданнями опозиціонери вважали вироблення альтернативних законопроєктів, а також "пропаганду ідей розпуску Верховної Ради і проведення нових демократичних виборів"

29 Яків Зайко “Заява Демократичного блоку України”, Бюлетень Верховної Ради УРСР, №. 31, (1990): 6 .

${ }^{30}$ Віталій Карпенко “Займіть свої місця... ”, Вітчизна, 1991, No. 4: 140

31 “Виступ народного депутата УРСР Д. Павличка”, Бюлетень Верховної Ради УРСР, №. 31 , (1990): 6.

32 Там само: 6-7. 
Після того, як В. Івашко вніс кандидатури на посаду першого заступника (серед них: Іван Плющ, Микола Хоменко і Василь Дурдинець), ще з однією заявою від опозиції виступив Роман Лубківський ${ }^{33}$. Це звернення було витримане у поміркованіших тонах, ніж попереднє, але і в ньому йшлося про перехід Демблоку в опозицію. Поява двох заяв із одного і того ж приводу свідчила, що в середовищі опозиційного об'єднання виокремилися політичні течії, які мають власне бачення розвитку подій у парламенті та кроків щодо реагування на них.

Прояснення ситуації навколо розбіжностей у стані опозиції довелося чекати недовго. Вже через два дні І. Юхновський розцінив вимогу розпуску Верховної Ради як неприйнятну для прихильників ідеї конструктивної опозиції. “Опозиція створюється не для того, щоб спостерігати, як тяжко живеться керівництву Верховної Ради і Урядові в умовах вільного ринку, а щоб конструктивно сприяти розвитку України", - заявив тоді І. Юхновський, висловлюючи надію на можливість змінити становище в Україні через прогресивні закони і співпрацю ${ }^{34}$

Протилежної думки дотримувалася Радикальна фракція, яка остаточно сформувалася у складі Народної Ради 15 червня 1990 р. Члени цієї фракції звинувачували окремих представників демократичного блоку в “тактичних помилках" i “угодовстві”. Погляди цієї частини депутатів були заманіфестовані в “Декларації тринадцяти” (Я. Зайко, Степан Хмара, Л. Лук’яненко та ін.) і “Платформі радикальної опозиціі”. Основні гасла, які задекларовано в цих документах були: створення незалежної держави із наступним формуванням конфедерації суверенних держав; жодної співпраці з урядом і партократією, розгортання кампанії громадянської непокори; скликання Народного Конгресу (Народної Ради) за участю радикальних депутатів усіх рівнів; розпуск Верховної Ради і вироблення політичної платформи нових демократичних виборів. Риску у процесі фракційного розмежування Народної Ради підвів Я. Зайко, заявивши: "Мені надано можливість висловити організаційну ідею фактичного існування двох фракцій у Демблоці - “Опозиції” і “Коаліції” (умовно)”35.

Поступово в демократичному депутатському таборі сформувалися кілька течій, які публічно задекларували свої політичні пріоритети, однак, як констатував В. Чорновіл, попри розбіжності у питаннях тактики парламентської боротьби Демблок “виявився на диво змобілізованим, що, очевидно, зв'язано з тим, що ми опинилися перед фактом “подавляющего большенства”, і сама атмосфера нас з'єднала докупи"з6.

33 “Виступ народного депутата УРСР Р. Лубківського”, Бюлетень Верховної Ради УРСР, o. 31 (1990): 12.

34 “Виступ народного депутата УРСР І. Юхновського”, Бюлетень Верховної Ради УРСР, №. 34 (1990): 38.

35 Яків Зайко "Парламентська криза - вінець кризи економічної, екологічної, політичної та духовної", Голос, №. 6 (1990): 4.

${ }^{36}$ В'ячеслав Чорновіл. “Тяжка ноша демократичних сил”, Молода Украйна. No. 10 (1990): 1. 
ISSN 2078-6077. Наукові зошити історичного факультету Львівського університету. 2018-2019. Випуск 19-20. Proceedings of History Faculty of Lviv University. 2018-2019. Issue 19-20.

Виявом єдности парламентської опозиції стала поява “Декларації принципів Народної Ради”. Головними засадами своєї діяльности у парламенті опозиційні сили вважали забезпечення державного суверенітету України, створення багатопартійного парламенту та запровадження різних форм власности. Суверенітет мав гарантуватися домінантою республіканських законів над загальносоюзними і переходом союзної власности у власність УРСР. Декларація наголосила на організаційному оформленні Народної Ради, що давало опозиції переваги у процедурних питаннях, зокрема, можливість готувати співдоповіді під час обговорення законопроєктів.

Парламентська більшість назагал спокійно сприйняла створення опозиційного блоку, однак, протестувала проти назви “Народна Рада". Олександр Мороз, майбутній лідер комуністичної більшости, заявив, що така назва "веде до конфронтаційних процесів у парламенті”. У відповідь І. Юхновський запевнив опонентів, що “опозиція буде працювати мудро” і зазначив, що “нехай це не ріже вам вухо, бо, зрештою, суть важлива, а суть буде добра"з7.

Процес формування керівництва парламенту завершився прогнозованим обранням першим заступником спікера Верховної Ради голови Київського облвиконкому Івана Плюща. Народна Рада відмовилася взяти участь у виборах заступника голови парламенту і відкликала свої кандидатури на цю посаду (І. Юхновський і Олександр Смець). Тоді заступником Голови було обрано В. Гриньова, політика, близького за поглядами до коаліційного парламентського об'єднання. Не погодившись із демаршем опозиції, він незняв свою кандидатуру, мотивуючи це необхідністю усім політичним силам брати активну участь у конструктивній діяльності парламенту.

Організаційне становлення демократичної меншости, значна підтримка Народної Ради громадськістю республіки (особливо в західному perioнi) i декларування ії лідерами “конструктивної опозиційности” - все це змушувало парламентське керівництво до діялогу з політичними опонентами. Одним із перших результатів такого діялогу стало укладення "джентльменської угоди" між Народною Радою та В. Івашком про вибір голів парламентських комісій членів Президії. У результатів цих домовленостей народорадівці очолили 7 із 23 постійних комісій. Як зазначив згодом І. Юхновський, “входження членів Народної Ради у Президію мало важливе (а в окремі історичні періоди і вирішальне) значення для впливу на подальшу роботу всього депутатського корпусу, Президії парламенту і Верховної Ради в цілому"з8.

Отже, політичні реформи періоду перебудови започаткували докорінну реорганізацію принципів діяльности вищих органів влади республіканського рівня.

37 “Виступ народного депутата УРСР І. Юхновського”, Бюлетень Верховної Ради УРСР, №. 34, (1990): 39.

${ }^{38}$ Ігор Юхновський Украӥна - незалежна держава. (Львів: Західний науковий центр АН України, 1994), 7. 
У березні 1990 р. відбулися відносно вільні й змагальні вибори до вищого законодавчого органу республіки - Верховної Ради. За результатами виборчої кампанії уперше в радянський період опозиційні комуністичній системі діячі увійшли до складу Верховної Ради республіки й отримали можливість задекларували свої погляди й політичні цілі у всеукраїнському масштабі. У Верховній Раді опозиційно налаштовані депутати згуртувалися у парламентське об’єднання «Демократичний блок». Опозиційний депутатський корпус у Верховній Раді вже на початках своєї діяльности зіткнувся з організаційним $і$ політичним диктатом партократичної більшости. Спроби опозиції врівноважити політичні інтереси більшости і меншости наштовхувались на глуху стіну неприйняття більшістю демократичних норм і процедур, характерних для системи парламентаризму. В умовах жорсткого політичного протистояння парламентська меншість заявила про організацій конструювання парламентського опозиційного блоку - Народної Ради: У Народну Раду увійшли представники різних ідейно-політичних течій, що, однак, перебували на спільних політичних платформах - антикомунізму, антитоталітаризму, антиунітаризму i демократизму. Посилення опозиційного депутатського корпусу відбулося завдяки входженню до Народної Ради групи депутатів, які репрезентували демократичні структури південного-сходу республіки (зокрема, Демократичну платформу КПУ), що, одночасно, зумовило іiі глибшу політичну диференціяцію. У своєму програмному маніфесті Народна Рада задекларувала реформу політичної системи в республіці на основі трьох засадничих принципів - суверенітет, багатопартійність і різноманітність форм власности. Народна Рада сформувалася як загальнополітичний парламентський блок у складі кількох фракцій (на першому етапі - «демократична» $\mathrm{i}$ «радикальна» фракції), кожна 3 яких мала власне бачення суспільно-політичної ситуації в республіці, завдань, цілей і методів дій опозиційних сил.

Організаційне становлення демократичної меншости, значна підтримка Народної Ради громадськістю республіки і декларування їі лідерами “конструктивної опозиційности" - все це змушувало парламентське керівництво до діялогу з політичними опонентами.

У ході першого етапу роботи парламенту відбулися дві події, які наклали глибокий відбиток на всю каденцію Верховної Ради XII скликання. 3 одного боку, завершено організаційне оформлення парламентської опозиції під керівництвом I. Юхновського, з іншого, сформувалася організаційна структура депутатської більшости на чолі з О. Морозом - депутатська група “За радянську суверенну Україну” (неформальна назва - “група “239”). Саме у протиборстві та взаємодії цих двох парламентських сил протягом наступних місяців поступово, але невпинно вимальовувалися контури майбутньої державности України. 
ISSN 2078-6077. Наукові зошити історичного факультету Львівського університету. 2018-2019. Випуск 19-20. Proceedings of History Faculty of Lviv University. 2018-2019. Issue 19-20.

\title{
FORMATION OF THE OPPOSITIONAL PARLIAMENTARY BLOCK IN THE VERKHOVNA RADA OF THE UKRAINIAN SSR (1990)
}

\author{
Ihor PIDKOWA \\ Ivan Franko National University of Lviv \\ the Mykhailo Hrushevskyi Department of Modern History of Ukraine \\ Universytetska str. 1, 79000, Lviv, Ukraine \\ e-mail: ihorpidkowa@gmail.com
}

In summer 1990 an oppositional parliamentary block - Narodna Rada (People's Council) was established in Verkhovna Rada of the Ukrainian SSR. This bloc played a key role in the political transformations of the republic and proclaiming its independence. The main thesis of the article is that Narodna Rada became the first parliamentary opposition in the history of Soviet Ukraine. Its program was anticommunistic, antiunitary and democratic, its social structure was significantly different from the parliamentary communist majority. The opposition played the key role in political structuring of the parliament, democratization of the entire Ukrainian society and gaining a status of a sovereign state.

In March 1990 during the first relatively democratic elections, the anticommunistic opposition won a significant representation in the newly elected parliament. Democratic deputies united in the Democratic block, that in a short time took the name Narodna Rada. The oppositional coalition using parliamentary and extraparliamentary methods, demanded changes in the local law, promoted development of democratic processes in the society and struggled for the state sovereignty of the republic. The democratic bloc was defeated in the elections of the parliamentary leaders, however the bloc used the parliamentary tribune ( in the conditions of the CPU full control over the media) to demonstrate its program to the society and gain political sympathy among Ukrainian citizens. Narodna Rada announced basic principles of its activity in the parliament: the sovereignty of the republic, a multiparty system and freedom of economic activity. Having declared their position, many deputies of Narodna Rada were looking for compromises with their political opponents, in order to protect economic interests of the Ukrainian SSR.

The opposition demanded liquidation of the communist party monopoly in the government, prevented gaining the leadership in the Parliament by conservative wing of the Communist Party, struggled for participation of democratic deputies in the governing bodies of the Parliament. With the emergence of organized parliamentary opposition, was held political structuring of parliament in conservative-communist majority "For Soviet Sovereign Ukraine" and democratic minority - Narodna Rada. The opposition made visible steps towards political pluralism and democratic society through the formation of a multiparty system. The deputies of Narodna Rada took part in the creation of alternative political organizations of the Communist Party, often leading the newly-formed party themselves. Professional structure of the opposition testified the lack of political experience of its members, but at the same time, high potential of the Narodna Rada members as participants in the legislative process. Under political pressure of Narodna Rada, the Parliament of Ukraine gradually turned into a professional representative body. Narodna Rada was represented by leaders of political organizations and Initiative politicians, who played a leading role in the socio-political processes in Ukraine. All political steps of the opposition were dedicated to make Ukraine an independent state.

Keywords: Verkhovna Rada, Ukraine, opposition, Soviet, USSR.

\section{REFERENCES}

About the constituent congress of the Liberal Democratic Party of Ukraine, Central State Archive of Public Organization of Ukraine, Fund 1, Series 32, File 2768. (in Ukrainian). About the press-conference of the Democratic Party of Ukraine, Central State Archive of Public Organization of Ukraine, Fund 1, Series 32, File 2905. (in Ukrainian). 
About the Second Nationwide Ukrainian meeting of the Narodniy Rukh, Central State Archive of Public Organization of Ukraine, Fund 1, Series 32, File 2768. (in Ukrainian).

Barabash Oleksandr, Verkhovna Rada of the Ukrainian SSR. 1990-1994. Kyiv: “Kyi”, 1998. (in Ukrainian).

Baran Volodymyr, Ukraine: contemporary history (1945-1991 ðð.). (Lviv: Instytut ukrainoznavstva im. I. Kryp'yakevycha, 2003).

Boyko Vitaliy, “Whom have we chosen?", Radians 'ka Ukraina, 24 March, 1990: 1. (in Ukrainian).

ChorNovil Vyacheslav. "A grieve burden of democratic forces", Moloda Ukraina, No.10, (1990): 1. (in Ukrainian).

Haran' Oleksiy, To kill the Dragon. From history of the Movement and new parties of Ukraine (Kyiv: "Lybid"”, 1993). (in Ukrainian).

Hryzak Yaroslav, Sketch of the History of Ukraine. Formation of the XIX-XX century modern nation (Kyiv: "Geneza", 1996). (in Ukrainian).

Karpenko Vitaliy, “Take your places”, Vitchyzna, No. 4 (1991): 140. (in Ukrainian).

Kravchuk Leonid, We have what we have. Memories and reflections (Kyiv: Stolittya, 2002), 51. (in Ukrainian).

Luk'yanenko Levko, "And I caught up no filth". Ukraina, September (1990): 9. (in Ukrainian).

Narodna Rada at the Ukrainian Parliament", Literaturna Ukraina, June 14, 1990: 2. (in Ukrainian).

Public speech of People's Deputy A. Tolstoukhov", Bulletin of UkrSSR Verkhovna Rada, No.28, (1990): 29. (in Ukrainian).

Public speech of People's Deputy D. Pavlychko", Bulletin of UkrSSR Verkhovna Rada, No.31, (1990): 6-7. (in Ukrainian).

Public speech of People's Deputy D. Zakharuk", Bulletin of UkrSSR Verkhovna Rada, No.26, (1990): 10. (in Ukrainian).

Public speech of People's Deputy O. Vorobyov", Bulletin of UkrSSR Verkhovna Rada, No.25, (1990): 5. (in Ukrainian).

Public speech of People's Deputy R. Lubkivskiy", Bulletin of UkrSSR Verkhovna Rada, No.31, (1990): 12. (in Ukrainian).

Public speech of People's Deputy S. Golovatiy", Bulletin of UkrSSR Verkhovna Rada, No.3, (1990): 12. (in Ukrainian).

Public speech of People's Deputy V. Chornovil", Bulletin of UkrSSR Verkhovna Rada, No.23 (1990): 51, 53. (in Ukrainian).

Public speech of People's Deputy V. Gryniov", Bulletin of UkrSSR Verkhovna Rada, No.23, (1990): 27, 36. (in Ukrainian).

Public speech of People's Deputy ${ }^{2}$. Yukhnovski”, Bulletin of UkrSSR Verkhovna Rada, No.34, (1990): 39. (in Ukrainian).

Public speech of People's Deputy 2. Yukhnovskiy", Bulletin of UkrSSR Verkhovna Rada, No.21, (1990): 58, No. 34 (1990): 38. (in Ukrainian).

Shulha Mykola, "Interview of the Head of the UkrSSR Verkhovna Rada Commission on the issues of sovereignty, inter-republican and international affairs", Vitchyzna, No. 3 (1991): 128-129. (in Ukrainian).

Statement of D. Pavlychko to Kyiv KPU organization, 22 March 1990, Central State Archive of Public Organization of Ukraine, Fund 1, Series 32, File 2767. (in Ukrainian).

Statement of I.Drach to Kyiv KPU organization, 20 March 1990, Central State Archive of Public Organization of Ukraine, Fund 1, Series 32, File 2767. (in Ukrainian). 
ISSN 2078-6077. Наукові зошити історичного факультету Львівського університету. 2018-2019. Випуск 19-20. Proceedings of History Faculty of Lviv University. 2018-2019. Issue 19-20.

Statement of the CEC Chairman at the UkrSSR parliamentary elections, Mai 15, 1990”, Bulletin of UkrSSR Verkhovna Rada, No.1, (1990): 3. (in Ukrainian).

Vitaliy Karpenko "Take your places ", Vitchyzna, No.4, (1990): 140. (in Ukrainian).

YukhNovs'kyi Ihor, Ukraine - an independent state (Lviv, 1994). (in Ukrainian).

Zayko Yakiv, "Statement of the Democratic Bloc of Ukraine", Bulletin of UkrSSR Verkhovna Rada, No.31, (1990): 6. (in Ukrainian).

Zayko Yakiv, "Parliamentary crisis - culmination of economic, environmental, political and spiritual crises", Holos, No.6, (1990): 4. (in Ukrainian). 